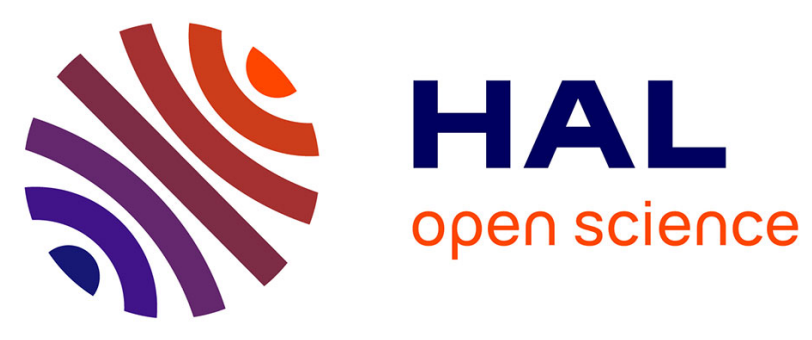

\title{
Backbone and side-chain proton NMR assignment in fully protonated proteins: microcrystals, sedimented assemblies, and amyloid fibrils
}

Jan Stanek, Loren B Andreas, Kristaps Jaudzems, Diane Cala, Daniela Lalli, Andrea Bertarello, Tobias Schubeis, Inara Akopjana, Svetlana Kotelovica, Kaspars Tars, et al.

\section{To cite this version:}

Jan Stanek, Loren B Andreas, Kristaps Jaudzems, Diane Cala, Daniela Lalli, et al.. Backbone and side-chain proton NMR assignment in fully protonated proteins: microcrystals, sedimented assemblies, and amyloid fibrils. Angewandte Chemie International Edition, 2016, 55 (50), pp.15504-15509. 10.1002/anie.201607084 . hal-01567784

\section{HAL Id: hal-01567784 \\ https://hal.science/hal-01567784}

Submitted on 24 Jul 2017

HAL is a multi-disciplinary open access archive for the deposit and dissemination of scientific research documents, whether they are published or not. The documents may come from teaching and research institutions in France or abroad, or from public or private research centers.
L'archive ouverte pluridisciplinaire HAL, est destinée au dépôt et à la diffusion de documents scientifiques de niveau recherche, publiés ou non, émanant des établissements d'enseignement et de recherche français ou étrangers, des laboratoires publics ou privés.

\section{(ㅇ)(1) $\$$}

Distributed under a Creative Commons Attribution - NonCommercial - NoDerivatives $\mid 4.0$ 


\title{
Backbone and side-chain proton NMR assignment in fully protonated proteins: microcrystals, sedimented assemblies, and
} amyloid fibrils

\author{
Jan Stanek, ${ }^{[a]}$ Loren B. Andreas,${ }^{[a]}$ Kristaps Jaudzems,${ }^{[a]}$ Diane Cala,${ }^{[a]}$ Daniela Lalli, ${ }^{[a]}$ Andrea \\ Bertarello, ${ }^{[\mathrm{a}]}$ Tobias Schubeis, ${ }^{[\mathrm{a}]}$ Inara Akopjana, ${ }^{[\mathrm{b}]}$ Svetlana Kotelovica, ${ }^{[\mathrm{b}]}$ Kaspars Tars,${ }^{[\mathrm{b}]}$ Andrea \\ Pica, ${ }^{[c]}$ Serena Leone, ${ }^{[c]}$ Delia Picone,${ }^{[\mathrm{c}]}$ Zhi-Qiang Xu, ${ }^{[\mathrm{d}]}$ Nicholas E. Dixon, ${ }^{[\mathrm{d}]}$ Denis Martinez, ${ }^{[\mathrm{e}]}$ Mélanie \\ Berbon, ${ }^{[\mathrm{e}]}$ Nadia El Mammeri, ${ }^{[\mathrm{e}]}$ Abdelmajid Noubhani, ${ }^{[\mathrm{e}]}$ Sven Saupe,${ }^{[\mathrm{f}]}$ Birgit Habenstein, ${ }^{[\mathrm{e}]}$ Antoine \\ Loquet, ${ }^{[\mathrm{e}]}$ and Guido Pintacuda ${ }^{*}[\mathrm{a}]$
}

\begin{abstract}
We demonstrate sensitive detection of alpha protons of fully protonated proteins by solid-state NMR with $100-111 \mathrm{kHz}$ magic-angle spinning (MAS). The excellent resolution in the $\mathrm{C} \alpha-\mathrm{H} \alpha$ plane is demonstrated for 5 proteins, including microcrystals, a sedimented complex, a capsid and amyloid fibrils. A set of $3 D$ spectra based on a $\mathrm{C} \alpha-\mathrm{H} \alpha$ detection block was developed and applied for the sequence-specific backbone and aliphatic side-chain resonance assignment using only $500 \mu \mathrm{g}$ of sample. These developments accelerate structural studies of biomolecular assemblies available in submilligram quantities without the need of protein deuteration.
\end{abstract}

Proton detection ${ }^{[1]}$ at MAS rates up to $60 \mathrm{kHz}$ has revolutionized solid-state NMR investigations of microcrystalline samples, ${ }^{[2]}$ insoluble assemblies,,$\underline{[3]}$ and membrane proteins ${ }^{[3 a}$, 4$]$ by improving sensitivity and reducing the amount of sample required. Up to $60 \mathrm{kHz}$ MAS, optimal proton resolution requires extensive dilution of the proton dipolar interaction network. This can be achieved by complete ${ }^{[2 \mathrm{~d}, 2 \underline{\mathrm{h}}, 5]}$ or partial $\left.{ }^{[4 \mathrm{e}}, 4 \mathrm{f}, 6\right]$ deuteration, where ${ }^{1} \mathrm{H}$ can be reintroduced by chemical exchange with water.

Due to this dilution requirement, only amide protons have been used for detection in sequence specific protein assignment strategies. Analogous to the case in solution, resonance assignment proceeds efficiently using a series of 3D spectra with common ${ }^{15} \mathrm{~N}$ and ${ }^{1} \mathrm{H}$ dimensions, and with a third dimension encoding ${ }^{13} \mathrm{C} \alpha,{ }^{13} \mathrm{C}^{\prime}$ or ${ }^{13} \mathrm{C} \beta$ of either the same or the preceding residue, allowing linking of sequential ${ }^{15} \mathrm{~N}-{ }^{1} \mathrm{H}$ pairs. $\left.. \underline{[2 \mathrm{~h}}, \underline{3 \mathrm{a}}, \underline{4 b}\right]$

The upper limit of MAS frequency was recently increased to

[a] Dr. J. Stanek, Dr. L. B. Andreas, Dr. K. Jaudzems, Dr. D. Cala Dr. D. Lalli, A. Bertarello, Dr. T. Schubeis, Dr. G. Pintacuda Centre de RMN à Très Hauts Champs, Institut des Sciences Analytiques (UMR 5280 - CNRS, ENS Lyon, UCB Lyon 1), Université de Lyon, 5 rue de la Doua, 69100 Villeurbanne, France E-mail: guido.pintacuda@ens-lyon.fr

[b] Dr. I. Akopjana, Dr. S. Kotelovica, Pr. K. Tars

Biomedical Research and Study Centre, Rātsupītes 1, LV1067, Riga, Latvia

[c] Dr. A. Pica, Dr. S. Leone, Pr. D. Picone Department of Chemical Sciences, University of Naples Federico II Via Cintia, I-80126, Naples, Italy

[d] Dr. Z.-Q. Xu, Pr. N. E. Dixon School of Chemistry, University of Wollongong, NSW 2522, Australia

[e] Dr. D. Martinez, M. Berbon, N. El Mammeri, Dr. A. Noubhani, Dr. B. Habenstein, Dr. A. Loquet

Institute of Chemistry \& Biology of Membranes \& Nanoobjects (UMR 5248 CBMN - CNRS, University of Bordeaux, Bordeaux INP), All. Geoffroy Saint-Hillaire, 33600 Pessac, France.

[f] Dr. S. Saupe

Institut de Biochimie et de Génétique Cellulaire (UMR 5095, CNRS Université de Bordeaux), 33077 Bordeaux, France

Supporting information for this article is given via a link at the end of the document.
$111 \mathrm{kHz}$ with the introduction of 0.7 and $0.8 \mathrm{~mm}$ probes, $[2$, , 7] allowing higher sensitivity in multidimensional experiments ${ }^{[8]}$ and a further reduction of sample volume. ${ }^{[2 \mathrm{j}}, \underline{3 \mathrm{~d}]}$ Most importantly, this extends the methodology to fully protonated proteins, allowing the detection of alpha and side-chain protons at a resolution comparable with those of the amide groups. $\underline{[3 \mathrm{~d},} \underline{7 \mathrm{~b}}, \underline{9]}$

Here we show a strategy for ${ }^{1} \mathrm{H},{ }^{13} \mathrm{C}$ and ${ }^{15} \mathrm{~N}$ resonance assignment for fully protonated biological samples based on a suite of 3D spectra sharing $\mathrm{H} \alpha-\mathrm{C} \alpha$ pairs as sensitive and resolved probes at $>100 \mathrm{kHz}$ MAS and high magnetic field. We additionally use the same $\mathrm{H} \alpha-\mathrm{C} \alpha$ resonances as a starting point for propagation of assignments throughout side-chains. We expect this approach to be of critical importance for the determination of protein structures by solid-state NMR, since it removes the requirement for deuteration, which previously limited ${ }^{1} \mathrm{H}$ detection-based strategies due to problems with expression yields, protein refolding and amide proton exchange. ${ }^{[4 a]}$ Also it provides a reliable method for sequence specific assignment of aliphatic protons, which are ideal reporters of tertiary and quaternary structure. ${ }^{[9]}$

Less than $500 \mu \mathrm{g}$ of five fully protonated ${ }^{13} \mathrm{C},{ }^{15} \mathrm{~N}$-labelled protein samples was packed into a $0.7 \mathrm{~mm}$ MAS rotor. The cross-polarization heteronuclear single quantum correlation (CPHSQC) spectra acquired at $100-111 \mathrm{kHz}$ MAS show resolved ${ }^{13} \mathrm{C} \alpha-{ }^{1} \mathrm{H} \alpha$ resonances (Fig. 1) for a range of proteins in various aggregation states. They include small crystalline proteins GB1 ${ }^{[10]}$ and MNEI, $\stackrel{[1]}{ }$ and biological assemblies with a significantly higher degree of complexity, such as the Acinetobacter phage 205 nucleocapsid (AP205), $\beta_{2}$-clamp from E. coli DNA polymerase III, ${ }^{[12]}$ and the prion domain of HET-s in its amyloid fibrillar form. In AP205, 90 nearly equivalent dimers of the coat protein (AP205CP) assemble into a $2.5 \mathrm{MDa}$ particle of icosahedral symmetry. ${ }^{[13]} \beta_{2}$ sliding clamp is a $81 \mathrm{kDa}$ circular dimer which was immobilized by sedimentation. ${ }^{[14]}$ Lastly, the prion domain of HET-s (218-289) aggregates into fibrils with a parallel in-register amyloid core showing a triangular $\beta$ solenoid fold. ${ }^{[15]}$

Each of these resolved ${ }^{13} \mathrm{C}-{ }^{1} \mathrm{H}$ dipolar-based correlations was obtained in approx. 30 minutes, providing a sensitive fingerprint at site-specific resolution without the need for sample deuteration. The ${ }^{13} \mathrm{C} \alpha-{ }^{1} \mathrm{H} \alpha$ region shows similar dispersion in chemical shift for proton and heteronuclei (approx. 3 and $30 \mathrm{ppm}$ ) as that observed in ${ }^{1} \mathrm{H}-{ }^{15} \mathrm{~N}$ correlation spectra (Fig. S1), and in contrast to ${ }^{1} \mathrm{H}-{ }^{15} \mathrm{~N}$ spectra, allows detection of prolines. In the case of GB1, we found that ${ }^{1} \mathrm{H} \alpha$ and ${ }^{1} \mathrm{H}^{\mathrm{N}}$ line widths are the same within experimental error, averaging to about $105 \mathrm{~Hz}$ 

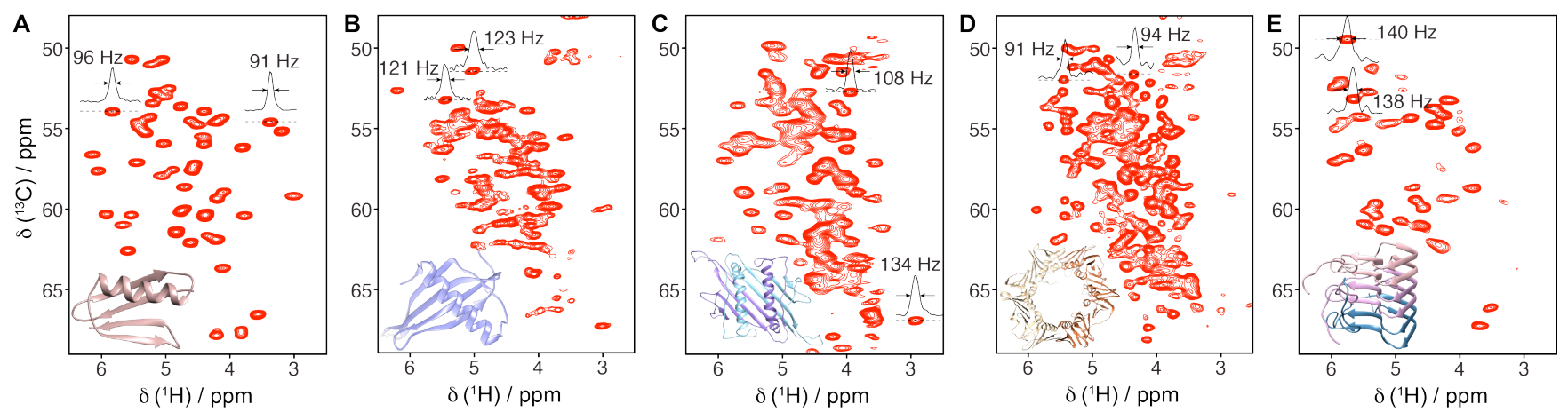

Figure 1. $\mathrm{H} \alpha-\mathrm{C} \alpha$ regions of $\mathrm{CP}{ }^{13} \mathrm{C}-\mathrm{HSQC}$ spectra of microcrystalline proteins $\mathrm{GB} 1$ (A) and MNEI (B), AP205 coat protein dimer assembling a nucleocapsid (C), sedimented $\beta_{2}$ sliding clamp (D) and HET-s construct (218-289) forming amyloid fibrils (E). 1D traces with representative proton line widths are reported for isolated peaks. Spectra were acquired on a $1 \mathrm{GHz}$ NMR spectrometer at MAS rates of 111 (A, B, D) and $100 \mathrm{kHz}(\mathrm{C}, \mathrm{E})$.

(Fig. S2), and comparable line widths were also observed for many isolated signals in the other four samples. This is nearly as narrow as the best-case $70 \mathrm{~Hz}$ line width that corresponds to the inherent heterogeneity of microcrystalline GB1 (see SI).

Notably, a significant improvement in resolution is observed for these correlations with respect to the previously accessible MAS standard of $60 \mathrm{kHz}$ due to a significant increase in the bulk ${ }^{1} \mathrm{H}$ and ${ }^{13} \mathrm{C}$ coherence lifetime $\mathrm{T}_{2}$ '. For the $\beta_{2}$ clamp and HET-s samples, lifetimes of 3.0 and 2.5 (for ${ }^{1} \mathrm{H}$ ) and 22 and $28 \mathrm{~ms}$ (for ${ }^{13} \mathrm{C} \alpha$ ) were reached at $100 \mathrm{kHz}$ MAS, respectively, which are noticeably shorter than for microcrystalline proteins. ${ }^{[9]}$ Nevertheless, estimated residual homogeneous ${ }^{1} \mathrm{H}$ line broadening is only $70 \mathrm{~Hz}$ (for GB1), $110 \mathrm{~Hz}$ (for AP205CP), $105 \mathrm{~Hz}$ (for $\beta_{2}$ clamp) and $130 \mathrm{~Hz}$ (for HET-s) in the fastest MAS regime currently available, and enables one to observe resolved $\mathrm{H} \alpha-\mathrm{C} \alpha$ correlations for all proteins studied here.

To exploit the favorable resolution and sensitivity of the $\mathrm{H} \alpha$ resonances, we developed a suite of $3 D$ experiments for sequential backbone and side-chain assignment that employ $\mathrm{C} \alpha-\mathrm{H} \alpha$ correlation as the detection scheme. We used two complementary 3D pulse sequences, $(\mathrm{H}) \mathrm{N}(\mathrm{CO}) \mathrm{CAH}$ and $(\mathrm{H}) \mathrm{NCAH}, \stackrel{[2 \mathrm{e}]}{\mathrm{a}}$ to record inter- and intra-residue correlations, respectively, as shown schematically in Fig. 2A-B (also more detailed in Fig. S3). These allow to sequentially link $\mathrm{H} \alpha-\mathrm{C} \alpha$ resonance pairs by matching a common ${ }^{15} \mathrm{~N}$ chemical shift.

An additional pair of 3D spectra, $(\mathrm{H}) \mathrm{CO}(\mathrm{N}) \mathrm{CAH}$ and (H)COCAH was also developed to link sequential $\mathrm{C} \alpha-\mathrm{H} \alpha$ pairs based on correlations to a common ${ }^{13} \mathrm{C}^{\prime}$ chemical shift.
A $(\mathrm{H}) \mathrm{NCAH}$

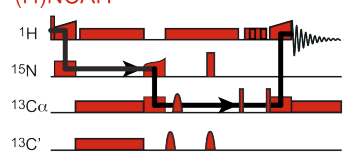

(H)N(CO)CAH

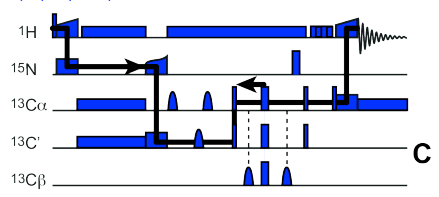

(H)COCAH
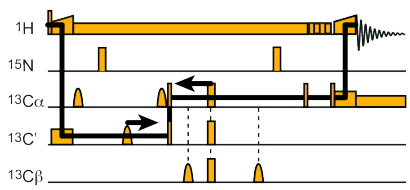

$(\mathrm{H}) \mathrm{CO}(\mathrm{N}) \mathrm{CAH}$

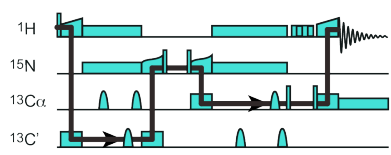

${ }^{13 C^{\prime}} \longrightarrow-1$

$(\mathrm{H})(\mathrm{CA}) \mathrm{CBCAH}$

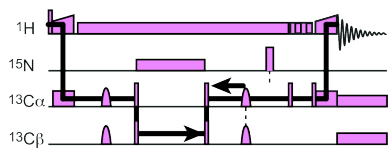

B
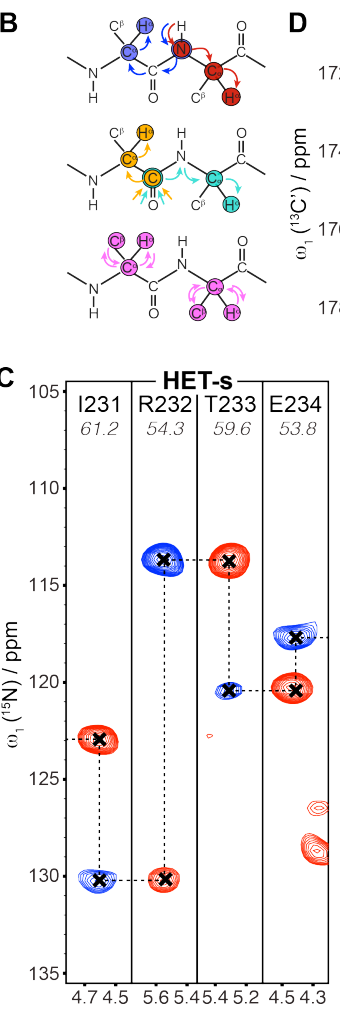

$\omega_{3}\left({ }^{1} \mathrm{H} \alpha\right) / \mathrm{ppm}$
D

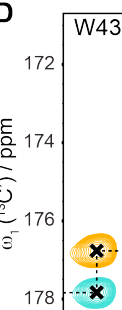

$(44+145$
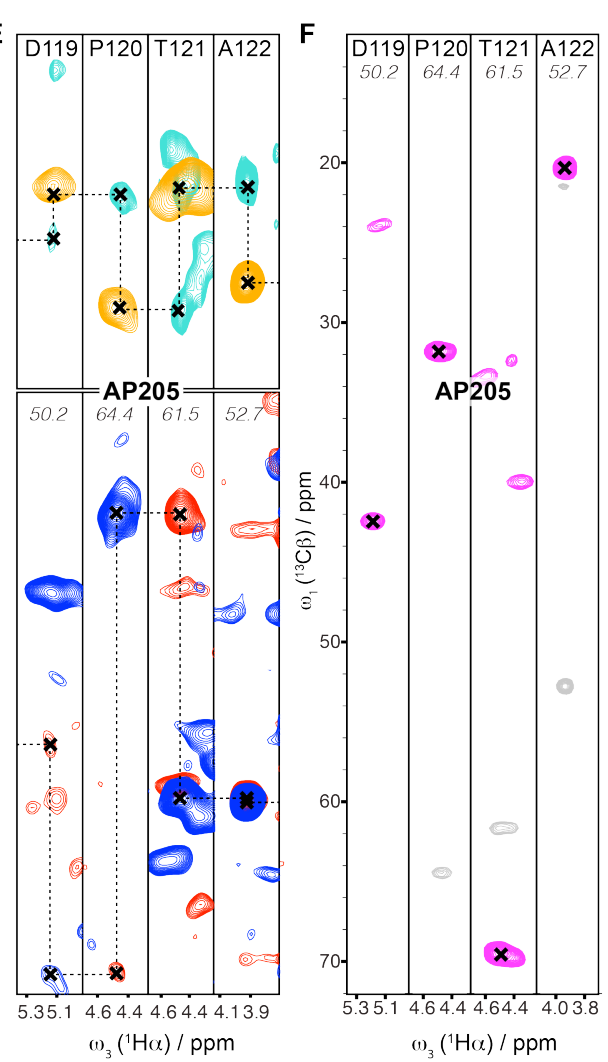

Figure 2. Simplified pulse sequence diagrams with indirect $\left({ }^{13} \mathrm{C}\right.$ and $\left.{ }^{15} \mathrm{~N}\right)$ chemical shift evolution periods denoted with arrows $(\mathrm{A})$. The irradiation schemes employed for these five experiments incorporate from 2 to 4 heteronuclear dipolar transfers (between $\mathrm{H}-\mathrm{N}, \mathrm{H}-\mathrm{C}, \mathrm{N}-\mathrm{C}$ ), and ${ }^{13} \mathrm{C}-{ }^{13} \mathrm{C} \alpha$ and ${ }^{13} \mathrm{C} \beta-{ }^{13} \mathrm{C} \alpha \mathrm{J}-$ based transfers. The long lifetimes at above $100 \mathrm{kHz}$ MAS are thus the key to high sensitivity in these sophisticated experiments involving multiple dimensions and transfer steps (Fig. S5). Schematic illustration of magnetization flow in the proposed 5 correlation experiments (B). Representative $2 \mathrm{D}$ cross-sections from ${ }^{15} \mathrm{~N}$ (blue and red), ${ }^{13} \mathrm{C}$-linked (cyan and orange) H $\alpha$-detected spectra for HET-s (C), GB1 (D) and AP205CP (E), along with the respective intra-residue C $\beta$-C $\alpha$-H $\alpha$ correlations for AP205 (F). 
Simultaneous matching of ${ }^{15} \mathrm{~N}$ and ${ }^{13} \mathrm{C}^{\prime}$ chemical shifts resolves ambiguities and ensures high reliability of the sequential assignment. Among backbone nuclei, ${ }^{15} \mathrm{~N}$ and ${ }^{13} \mathrm{C}^{\prime}$ were found to have the most favorable resolution (chemical shift dispersion with respect to line width), and thus provide the least ambiguous sequential matching. ${ }^{[8 b]}$ In contrast to the sibling strategy developed for solution-state NMR, ${ }^{[16]}$ residual water signal is efficiently suppressed and has no adverse impact on sensitivity of the $\mathrm{H} \alpha$-detected experiments. A fifth pulse sequence, $(\mathrm{H})(\mathrm{CA}) \mathrm{CBCAH}$ (bottom panel in Fig. $2 \mathrm{~A}$ ), was designed to provide access to ${ }^{13} \mathrm{C} \beta$ chemical shifts, which are of great relevance for determination of residue type and thus essential for the alignment of the linked stretches of $\mathrm{H} \alpha-\mathrm{C} \alpha$ pairs with the primary sequence. Additionally, the simultaneous presence of two ${ }^{13} \mathrm{C}$ dimensions provides great precision for the difference $\left({ }^{13} \mathrm{C} \alpha-{ }^{13} \mathrm{C} \beta\right)$, a parameter directly correlated to secondary structure and important during structure modeling.

For fully-protonated proteins, the experiments described above play an equivalent role as the suite of $\mathrm{H}^{\mathrm{N}}$-detected sequences for deuterated systems. ${ }^{[4 \mathrm{~b}]}$ As a particular advantage here, $\mathrm{H} \alpha$-detection provides access to intraresidue ${ }^{13} \mathrm{C} \beta$ and ${ }^{13} \mathrm{C}^{\prime}$ shifts with significantly higher sensitivity with respect to $\mathrm{H}^{\mathrm{N}}$ detection, due to shorter coherence transfer pathways. Also, unlike $\mathrm{H}^{\mathrm{N}}$-detection, the proposed $\mathrm{H} \alpha$-detected experiments enable the sequential walk over prolines, making them a method of choice for sequential assignment of proline-rich proteins. ${ }^{[16]}$ Proline resonances usually show higher intensity in the ${ }^{13} \mathrm{C}^{\prime}$ linking pair of spectra (Fig. 2E).

Representative strip plots showing the sequential walk for HET-s, GB1 and AP205 are shown in Fig. 2C-E. For the case of GB1, we obtained all expected correlations (Fig. S6) and for AP205CP we found 90, 98, 103 and 109 correlations in the 3D spectra (Fig. S7) and assigned in total $111(85 \%) \mathrm{H} \alpha-\mathrm{C} \alpha$ pairs of resonances. Missing peaks belong mostly to $\mathrm{N}$-terminal residues, an internal loop (R34-N46) and the C-terminus that show increased dynamics and cannot be efficiently detected in dipolar-coupling based transfers. For HET-s amyloid fibrils, we observed 41 out of 44 intraresidue correlations in the $\beta$-strands forming the rigid fibril core, i.e. N226-A248 and T261-Y281 (Fig. S8) and 40 of 42 expected interresidue correlations in the $(\mathrm{H}) \mathrm{N}(\mathrm{CO}) \mathrm{CAH}$ spectrum. The flexible loop, as reported for ${ }^{13} \mathrm{C}$ detected spectra, ${ }^{[17]}$ is not visible in CP-based experiments. The assigned CP-HSQC spectra of HET-s are shown in Fig. S9.

An alternative approach for $\mathrm{H} \alpha$ assignment would employ $\mathrm{H}^{\mathrm{N}}$-detection for sequential backbone assignment of ${ }^{13} \mathrm{C} \alpha$ and ${ }^{15} \mathrm{~N}$ shifts, ${ }^{[4 \mathrm{~b}]}$ followed by the use of an extra $(\mathrm{H}) \mathrm{NCAH}$ to transfer the assignment to $\alpha$-protons. ${ }^{[2]}$ However, this relies on the uniqueness of ${ }^{13} \mathrm{C} \alpha$ and ${ }^{15} \mathrm{~N}$ shift pairs, the condition which is often met only for systems as simple as GB1. In AP205, for example, all five $\mathrm{H} \alpha$-detected spectra were necessary to obtain assignment of $\alpha$-protons. Therefore, the set of spectra shown here represents the first general and stand-alone strategy for assignment of $\mathrm{H} \alpha$-proton shifts in the solid-state.

Assignment of $\alpha$-protons opens the way to assign side-chain protons, ${ }^{[18]}$ which are sensitive probes of protein environment and interactions. In GB1 at $111 \mathrm{kHz}$ MAS, side-chain ${ }^{1} \mathrm{H}$ resonances demonstrate $100-150 \mathrm{~Hz}$ line widths, which is sufficient for their use in structural investigations. ${ }^{\left[{ }^{[9}\right.} \mathrm{H} \alpha$-detected schemes can correlate ${ }^{1} \mathrm{H}$ and ${ }^{13} \mathrm{C}$ side-chain with backbone resonances using a shorter and thus more sensitive coherence transfer pathway compared to $\mathrm{H}^{\mathrm{N}}$-detected schemes. ${ }^{[19]} \mathrm{We}$ incorporated ${ }^{1} \mathrm{~J}_{\mathrm{CC}}$-mediated ${ }^{13} \mathrm{C}-{ }^{13} \mathrm{C}$ isotropic mixing ${ }^{[20]}$ into the $\mathrm{H} \rightarrow \mathrm{C} \rightarrow \mathrm{H}$ CP-HSQC. The resulting irradiation schemes, $\mathrm{H}(\mathrm{C}) \mathrm{CH}$ and $(\mathrm{H}) \mathrm{CCH}$, are shown in Fig. S4, and incorporate WALTZ-16
${ }^{13} \mathrm{C}$ mixing analogous to established TOBSY schemes. ${ }^{[1]]}$ High efficiency of ${ }^{13} \mathrm{C}$ mixing based on relatively weak $\mathrm{J}$-couplings results from long rotating-frame coherence lifetimes at 100 $111 \mathrm{kHz}$ spinning. For example, for GB1 $\mathrm{T}_{1} \rho\left({ }^{13} \mathrm{C} \alpha\right) \approx 130 \mathrm{~ms}$ is almost an order of magnitude longer compared to the time necessary to obtain a reasonably uniform exchange of magnetization between side-chain ${ }^{13} \mathrm{C}$ nuclei (typically $10-$ $15 \mathrm{~ms}$ ). The two spectra encode aliphatic side-chain ${ }^{1} \mathrm{H}$ or ${ }^{13} \mathrm{C}$ spins of a residue to each directly bonded pair such as $\mathrm{H} \alpha-\mathrm{C} \alpha$, $\mathrm{H} \beta$-C $\beta$, etc. (Fig. 3). Given that assignment of $\alpha$-resonances is available, these two spectra together enable to identify ${ }^{1} \mathrm{H}$ and ${ }^{13} \mathrm{C}$ chemical shifts further in the side-chains. The obtained values can be recursively used in the same way as the starting ${ }^{1} \mathrm{H} \alpha-{ }^{13} \mathrm{C} \alpha$ pair to complete and/or confirm the resonance assignment in case of ambiguity or low intensity of some crosspeaks. In Fig. 3, six cross-sections are displayed at the positions of all $\mathrm{H}-\mathrm{C}$ resonance pairs of isoleucine-124 of AP205CP and show a shared set of correlations to all aliphatic ${ }^{13} \mathrm{C}$ or ${ }^{1} \mathrm{H}$ resonances in this residue. One can appreciate the redundancy of information and mutual support for identification of side-chain signals, which stems from the fact that in principle, all intraresidue aliphatic ${ }^{13} \mathrm{C}$ or ${ }^{1} \mathrm{H}$ resonances are correlated to each directly bonded ${ }^{13} \mathrm{C}^{-1} \mathrm{H}$ spin pair. In AP205CP, the $(\mathrm{H}) \mathrm{CCH}$ (55h acquisition time) and $\mathrm{H}(\mathrm{C}) \mathrm{CH}(24 \mathrm{~h})$ resulted in assignment of $87 \%$ of side-chain ${ }^{1} \mathrm{H}$ and ${ }^{13} \mathrm{C}$ resonances for residues with assigned ${ }^{1} \mathrm{H} \alpha$ shifts (see $\left.\mathrm{SI}\right)$. In $\mathrm{GB} 1$, a single $(\mathrm{H}) \mathrm{CCH}(32.5 \mathrm{~h})$ resulted in $99.1 \%$ complete assignment of side-chain ${ }^{1} \mathrm{H}$ and ${ }^{13} \mathrm{C}$ resonances.

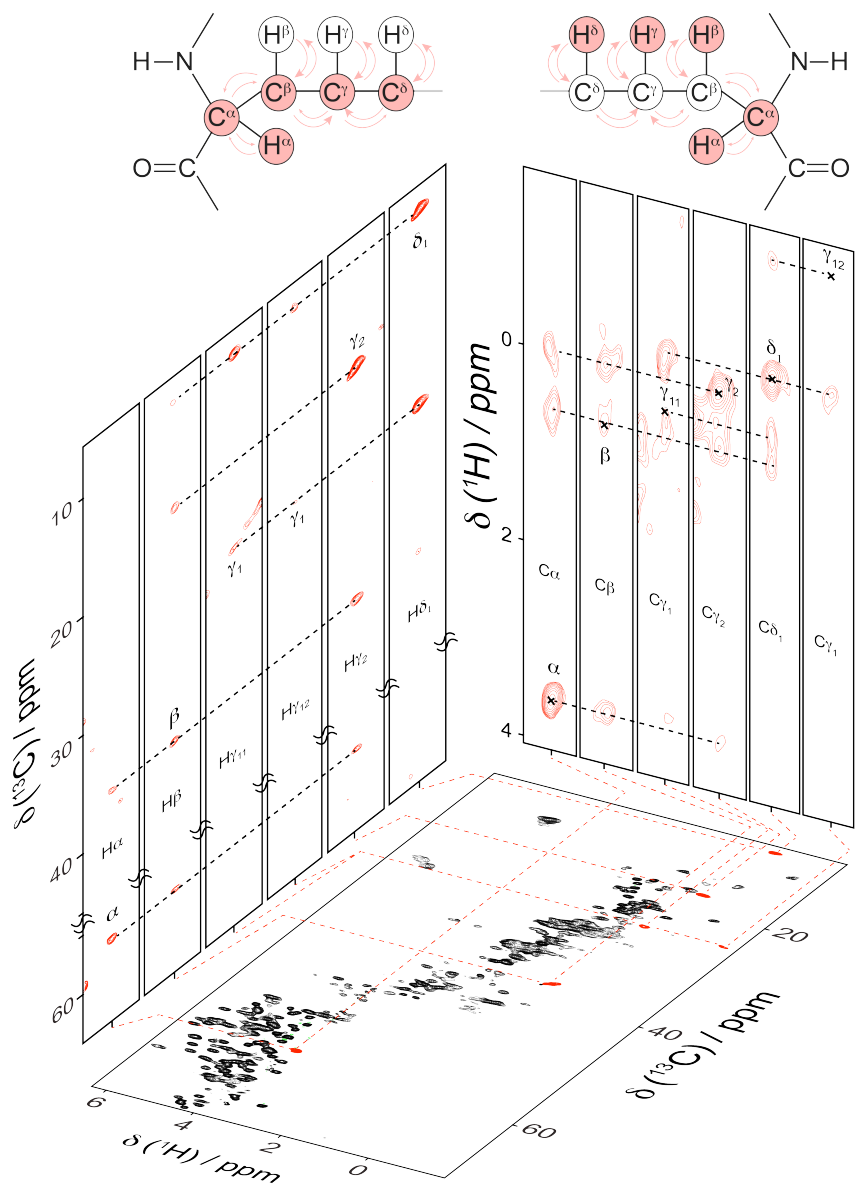

Figure 3. Representative cross-sections from $3 \mathrm{D}(\mathrm{H}) \mathrm{CCH}-$ and $\mathrm{H}(\mathrm{C}) \mathrm{CH}$ spectra for AP205CP shown on top of the aliphatic region of $2 \mathrm{D}{ }^{13} \mathrm{C}-{ }^{1} \mathrm{H}$ correlation spectrum. On the vertical axis the strips display ${ }^{13} \mathrm{C}$ or ${ }^{1} \mathrm{H}$ chemical shifts in the side-chain of isoleucine 124 obtained when navigating from six ${ }^{13} \mathrm{C}-{ }^{1} \mathrm{H}$ peaks in the ${ }^{13} \mathrm{C}-\mathrm{HSQC}$ belonging to this residue. The coherence pathways are sketched above the strips of corresponding 3D spectra. 
In conclusion, we demonstrated rapid side-chain ${ }^{1} \mathrm{H}$ and ${ }^{13} \mathrm{C}$ resonance assignment in fully-protonated proteins at very fast MAS rates $(100-111 \mathrm{kHz})$. For proteins of about $20 \mathrm{kDa}$ one week of experimental time and less than a milligram of sample are required, without the need of deuteration. The method can be widely applied not only to microcrystalline proteins, but also to viral nucleocapsids, amyloid fibrils and other protein assemblies or sediments. The accessibility of aliphatic ${ }^{1} \mathrm{H}$ chemical shifts is of great importance for structure determination based on ${ }^{1} \mathrm{H}-{ }^{1} \mathrm{H}$ distance restraints, accelerating solid-state NMR analysis for structural biology.

\section{Acknowledgements}

We acknowledge financial support from CNRS (IR-RMN FR3050 and Fondation pour la Chimie des Substances Naturelles), from the People Programme of the European Union's FP7 (FP7PEOPLE-2012-ITN n'317127 "pNMR"), and from the European Research Council (ERC) under the European Union's Horizon 2020 research and innovation programme (ERC-2015-CoG GA $n^{\circ} 648974$ to GP and ERC-2015-StG GA n`105945 to AL). LBA, $\mathrm{KJ}$ and JS are supported by three MC incoming fellowships (REA grant agreements $n^{\circ} 624918$ "MEM-MAS", n661175 "virus-DNP-NMR", n661799 "COMPLEX-FAST-MAS"). AP and SL are supported by Fondazione con il Sud (grant 2011-PDR19).

Keywords: magic-angle spinning $•$ proton detection $•$ resonance assignment $\cdot$ solid-state NMR spectroscopy

[1] a) A. E. McDermott, F. J. Creuzet, A. C. Kolbert, R. G. Griffin, J. Magn Reson. (1969-1992) 1992, 98, 408-413; b) Y. Ishii, R. Tycko, J. Magn. Reson. 2000, 142, 199-204.

[2] a) E. K. Paulson, C. R. Morcombe, V. Gaponenko, B. Dancheck, R. A Byrd, K. W. Zilm, J. Am. Chem. Soc. 2003, 125, 15831-15836; b) V. Chevelkov, B. J. van Rossum, F. Castellani, K. Rehbein, A. Diehl, M. Hohwy, S. Steuernagel, F. Engelke, H. Oschkinat, B. Reif, J. Am. Chem. Soc. 2003, 125, 7788-7789; c) V. Chevelkov, K. Rehbein, A. Diehl, B. Reif, Angew. Chem. Int. Ed. Engl. 2006, 45, 3878-3881; d) D. H. Zhou, J. J. Shea, A. J. Nieuwkoop, W. T. Franks, B. J. Wylie, C. Mullen, D. Sandoz, C. M. Rienstra, Angew. Chem. Int. Ed. Engl. 2007, 46, 8380-8383; e) D. H. Zhou, G. Shah, M. Cormos, C. Mullen, D. Sandoz, C. M. Rienstra, J. Am. Chem. Soc. 2007, 129, 11791-11801; f) M. Huber, S. Hiller, P. Schanda, M. Ernst, A. Bockmann, R. Verel, B. H. Meier, Chemphyschem 2011, 12, 915-918; g) R. Linser, B. Bardiaux, V. Higman, U. Fink, B. Reif, J. Am. Chem. Soc. 2011, 133, 5905-5912; h) M. J. Knight, A. L. Webber, A. J. Pell, P. Guerry, E. Barbet-Massin, I. Bertini, I. C. Felli, L. Gonnelli, R. Pierattelli, L. Emsley, A. Lesage, T. Herrmann, G. Pintacuda, Angew. Chem. Int. Ed. Engl. 2011, 50, 11697-11701; i) M. J. Knight, A. J. Pell, I. Bertini, I. C. Felli, L. Gonnelli, R. Pierattelli, T. Herrmann, L. Emsley, G. Pintacuda, Proc. Natl. Acad. Sci. USA 2012, 109, 11095-11100; j) V. Agarwal, S. Penzel, K. Szekely, R. Cadalbert, E. Testori, A. Oss, J. Past, A. Samoson, M. Ernst, A. Bockmann, B. H. Meier, Angew. Chem. Int. Ed. Engl. 2014, 53, 12253-12256.

[3] a) D. H. Zhou, A. J. Nieuwkoop, D. A. Berthold, G. Comellas, L. J. Sperling, M. Tang, G. J. Shah, E. J. Brea, L. R. Lemkau, C. M. Rienstra, J. Biomol. NMR 2012, 54, 291-305; b) P. Fricke, V. Chevelkov, C. Shi, A. Lange, J. Magn. Reson. 2015, 253, 2-9; c) R. Linser, M. Dasari, M. Hiller, V. Higman, U. Fink, J. M. L. del Amo, S. Markovic, L. Handel, B. Kessler, P. Schmieder, D. Oesterhelt, H. Oschkinat, B. Reif, Angew. Chem. Int. Ed. Engl. 2011, 50, 4508-4512; d) J. M. Lamley, D. luga, C. Öster, H.-J. Sass, M. Rogowski, A. Oss, J. Past, A. Reinhold, S. Grzesiek, A. Samoson, J. R Lewandowski, J. Am. Chem. Soc. 2014, 136, 16800-16806; e) J. M. Lamley, C. Öster, R. A. Stevens, J. R. Lewandowski, Angew. Chem. Int. Ed. Engl. 2015, 54, 15374-15378; f) P. Schanda, S. Triboulet, C. Laguri, C. M. Bougault, I. Ayala, M. Callon, M. Arthur, J. P. Simorre, J. Am. Chem. Soc. 2014, 136, 17852-17860; g) R. Linser, B. Bardiaux, L. B. Andreas, S. G. Hyberts, V. K. Morris, G. Pintacuda, M. Sunde, A. H. Kwan, G. Wagner, J. Am. Chem. Soc. 2014, 136, 11002-11010; h) H. R. Dannatt, M. Felletti, S. Jehle, Y. Wang, L. Emsley, N. E. Dixon, A. Lesage, G. Pintacuda, Angew. Chem. Int. Ed. Engl. 2016, 55, 6638-6641.

[4] a) M. E. Ward, L. Shi, E. Lake, S. Krishnamurthy, H. Hutchins, L. S. Brown, V. Ladizhansky, J. Am. Chem. Soc. 2011, 133, 17434-17443; b) E. Barbet-Massin, A. J. Pell, J. S. Retel, L. B. Andreas, K. Jaudzems, W. T. Franks, A. J. Nieuwkoop, M. Hiller, V. Higman, P. Guerry, A. Ber- tarello,
M. J. Knight, M. Felletti, T. Le Marchand, S. Kotelovica, I. Akopjana, K. Tars, M. Stoppini, B. Vittorio, M. Bolognesi, S. Ricagno, J. J. Chou, R. G. Griffin, H. Oschkinat, A. Lesage, L. Emsley, T. Herrmann, G. Pintacuda, J. Am. Chem. Soc. 2014, 136, 12489-12497; c) M. T. Eddy, Y. Su, R. Silvers, L. Andreas, L. Clark, G. Wagner, G. Pintacuda, L. Emsley, R. G. Griffin, J. Biomol. NMR 2015, 61, 299-310; d) L. B. Andreas, M. Reese, M. T. Eddy, V. Gelev, Q. Z. Ni, E. A. Miller, L. Emsley, G. Pintacuda, J. J. Chou, R. G. Griffin, J. Am. Chem. Soc. 2015, 137, 14877-14886; e) T Sinnige, M. Daniëls, M. Baldus, M. Weingarth, J. Am. Chem. Soc. 2014 136, 4452-4455; f) D. Mance, T. Sinnige, M. Kaplan, S. Narasimhan, M. Daniels, K. Houben, M. Baldus, M. Weingarth, Angew. Chem. Int. Ed. Engl. 2015, 54, 15799-15803.

[5] A. J. Nieuwkoop, W. T. Franks, K. Rehbein, A. Diehl, U. Akbey, F. Engelke, L. Emsley, G. Pintacuda, H. Oschkinat, J. Biomol. NMR 2015, 61, 161-171.

[6] S. Asami, K. Szekely, P. Schanda, B. H. Meier, B. Reif, J. Biomol. NMR 2012, 54, 155-168.

[7] a) Y. Nishiyama, M. Malon, Y. Ishii, A. Ramamoorthy, J. Magn. Reson. 2014, 244, 1-5; b) S. Wang, S. Parthasarathy, Y. Nishiyama, Y. Endo, T. Nemoto, K. Yamauchi, T. Asakura, M. Takeda, T. Terauchi, M. Kainosho, Y. Ishii, PLoS One 2015, 10, e0122714; c) S. Wang, S. Parthasarathy, Y. Xiao, Y. Nishiyama, F. Long, I. Matsuda, Y. Endo, T. Nemoto, K. Yamauchi, T. Asakura, M. Takeda, T. Terauchi, M. Kainosho, Y. Ishii, Chem. Commun. 2015, 51, 15055-15058.

[8] a) S. Penzel, A. A. Smith, V. Agarwal, A. Hunkeler, M. L. Org, A. Samoson, A. Bockmann, M. Ernst, B. H. Meier, J. Biomol. NMR 2015, 63 , 165-186; b) L. B. Andreas, J. Stanek, T. Le Marchand, A. Bertarello, D. C. Paepe, D. Lalli, M. Krejcikova, C. Doyen, C. Oster, B. Knott, S. Wegner, F. Engelke, I. C. Felli, R. Pierattelli, N. E. Dixon, L. Emsley, T. Herrmann, G. Pintacuda, J. Biomol. NMR 2015, 62, 253-261.

[9] L. B. Andreas, K. Jaudzems, J. Stanek, D. Lalli, A. Bertarello, T. Le Marchand, D. Cala-De Paepe, S. Kotelovica, I. Akopjana, B. Knott, S. Wegner, F. Engelke, A. Lesage, L. Emsley, K. Tars, T. Herrmann, G. Pintacuda, Proc Natl Acad Sci U S A 2016, 113, 9187-9192.

[10] W. T. Franks, D. H. Zhou, B. J. Wylie, B. G. Money, D. T. Graesser, H. L. Frericks, G. Sahota, C. M. Rienstra, J. Am. Chem. Soc. 2005, 127, 12291-12305.

[11] R. Spadaccini, O. Crescenzi, T. Tancredi, N. De Casamassimi, G. Saviano, R. Scognamiglio, A. Di Donato, P. A. Temussi, J. Mol. Biol. 2001, 305, 505-514.

[12] a) X. P. Kong, R. Onrust, M. O'Donnell, J. Kuriyan, Cell 1992, 69, 425437; b) A. J. Oakley, P. Prosselkov, G. Wijffels, J. L. Beck, M. C. Wilce, N. E. Dixon, Acta Crystallogr D 2003, 59, 1192-1199; c) R. E. Georgescu, S S. Kim, O. Yurieva, J. Kuriyan, X. P. Kong, M. O'Donnell, Cell 2008, 132, 43-54.

[13] S. H. van den Worm, R. I. Koning, H. J. Warmenhoven, H. K. Koerten, J. van Duin, J. Mol. Biol. 2006, 363, 858-865.

[14] a) I. Bertini, C. Luchinat, G. Parigi, E. Ravera, B. Reif, P. Turano, Proc Natl Acad Sci U S A 2011, 108, 10396-10399; b) C. Gardiennet, A. K. Schutz, A. Hunkeler, B. Kunert, L. Terradot, A. Böckmann, B. H. Meier, Angew. Chem. Int. Ed. Engl. 2012, 51, 7855-7858.

[15] C. Wasmer, A. Lange, H. Van Melckebeke, A. B. Siemer, R. Riek, B. H. Meier, Science 2008, 319, 1523-1526.

[16] S. Mäntylahti, O. Aitio, M. Hellman, P. Permi, J. Biomol. NMR 2010, 47, 171-181.

[17] A. B. Siemer, A. A. Arnold, C. Ritter, T. Westfeld, M. Ernst, R. Riek, B. H. Meier, J. Am. Chem. Soc. 2006, 128, 13224-13228.

[18] S. K. Vasa, P. Rovo, K. Giller, S. Becker, R. Linser, Phys. Chem. Chem. Phys. 2016, 18, 8359-8363.

[19]a) N. Kulminskaya, S. K. Vasa, K. Giller, S. Becker, A. Kwan, M. Sunde, R. Linser, Chem. Commun. 2016, 52, 268-271; b) R. Linser, J. Biomol. NMR 2011, 51, 221-226.

[20] A. Bax, G. M. Clore, A. M. Gronenborn, J. Magn. Reson. (1969-1992) $1990,88,425-431$

[21] a) M. Baldus, B. H. Meier, J. Magn. Reson. A 1996, 121, 65-69; b) E. H. Hardy, R. Verel, B. H. Meier, J. Magn. Reson. 2001, 148, 459-464; c) V. Agarwal, B. Reif, J. Magn. Reson. 2008, 194, 16-24. 


\section{COMMUNICATION}

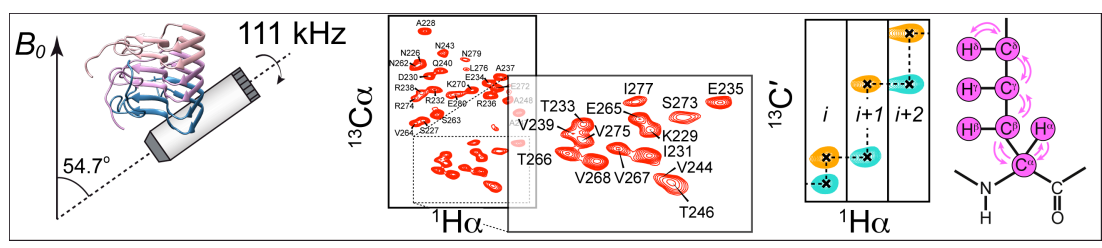

Side-chain protons are all back: with new $111 \mathrm{kHz}$ magic-angle spinning probes, high-resolution ${ }^{1} \mathrm{H}$-detected NMR spectroscopy of insoluble, crystalline or selfassembled protein aggregates is now feasible without replacing side-chain protons with deuterons. $\alpha$-Protons become sensitive and spectrally resolved NMR probes, which allow backbone and side-chain resonance assignment in about one week of experimental time for proteins of about $20 \mathrm{kDa}$.
J. Stanek, L. B. Andreas, K. Jaudzems,

D. Cala, D. Lalli, A. Bertarello,

T. Schubeis, I. Akopjana, S. Kotelovica,

K. Tars, A. Pica, S. Leone, D. Picone, Z.-

Q. Xu, N. E. Dixon, D. Martinez, M.

Berbon, N. El Mammeri, A. Noubhani, S. Saupe, B. Habenstein, A. Loquet, G. Pintacuda*

Page No. - Page No.

Backbone and side-chain proton NMR assignment in fully protonated proteins: microcrystals, sedimented assemblies, and amyloid fibrils 